\title{
To be or not to be a Scientist 2.0? \\ Open Access in Translatology \\ A German Case Study
}

Marco Agnetta

Saarland University, Germany

\section{Introduction}

Connoisseurs of linguistic mechanisms will not like the expression "scientist 2.0" which is employed in the title of the present study. This metaphor suggests that such a scientist would be an updated and ameliorated version of a sort of antiquated scientist 1.0. Although chosen as a provocative springboard, however, the question ("to be or not to be a scientist 2.0?") gets to the heart of a set of problems that arise out of presently changing scientific practices. Thus, why not begin with such a polemical wording in the title?

In recent years, a new conception of scientific activity for the 21st century has been put forward under the heading of "Open Science". This movement follows the recommendations formulated by the Budapest Open Access Initiative (BOAI 2001) and the Berlin Declaration on Open Access to Knowledge in the Sciences and Humanities (Berlin Declaration 2003) urging academic actors to ensure unrestricted access to knowledge, at least to that produced by themselves. In this context "Science 2.0" would mean the possibility (or utopian ideal?) of openly accessing any kind of knowledge resources produced or elaborated by researchers. "To be or not to be a Scientist 2.0?" is, therefore, a question that is becoming increasingly urgent in many disciplines, including also Contrastive Linguistics and Translatology. Paradoxically, this is occurring even though the indispensable adjustments specific to these disciplines that would follow from a positive response to the question have so far been neither defined nor applied. Nevertheless Open Access (OA) is flatly considered a revolutionary research practice (cf. Aschenbrenner et al. 2007: 21).

The present study does not try, nor is it able, to provide comprehensive solutions for these points of OA publishing which, more than a dozen years after the formulation of the above mentioned manifestos, are still denounced in our discipline. Within the framework of this study we will focus on the point of view of the academic actors on this new research and publication paradigm and we will investigate whether and to what extent realizations of OA endeavors can be found in contemporary German translatology. We will, therefore, explicitly refer to the activity of translation scholars and not to that 
of translators or interpreters, where OA has also been identified as a significant desideratum (cf. further literature in this volume).

\section{Openness in Translatological Research}

In the Internet age open access is a frequently and vehemently voiced request which heavily affects conventional production and marketing conditions; this equally applies to public funded research. This is, inter alia, proved by the constantly increasing number of institutions that commit to the OA principle (cf. the Registry of Open Access Repository Mandates and Policies, ROARMAP). Despite its status as a ubiquitous expression in public and research discourse, openness must always be exactly defined. In general, one can speak of open access where barriers between customers or users and their product of interest do not exist: openness is equal to freedom from barriers. The Open Knowledge Foundation (OKFN) gives a more concrete definition of openness with regard to knowledge and mentions the following three "key features of openness" (cf. OKFN n.d.):

- "Availability and access: the data must be available as a whole and at no more than a reasonable reproduction cost, preferably by downloading over the internet. The data must also be available in a convenient and modifiable form.

- Reuse and redistribution: the data must be provided under terms that permit reuse and redistribution including intermixing with other datasets. The data must be machine-readable.

- Universal participation: everyone must be able to use, reuse and redistribute - there should be no discrimination against fields of endeavour or against persons or groups. For example, 'noncommercial' restrictions that would prevent 'commercial' use, or restrictions of use for certain purposes (e.g. only in education), are not allowed" (ibid.).

These points can be summarised to the following succinct definition formula propagated by the OKFN: "Open data and content can be freely used, modified, and shared by anyone for any purpose" (Opendefinition n.d.). This definition, as well as a more verbose version of it, are presently available in 38 languages (cf. ibid.). To comply with this definition of openness, persons and institutions who make available any kind of information and knowledge should, therefore, remove the following types of barriers:

1) Access barriers: These arise when gaining full or partial access to goods and services, whatever their nature, is inhibited by any spatial 
and temporal conditions. We speak about technical barrier if we refer to the reduced accessibility to a certain medium.

2) Pay/price barriers: These arise when the access to and the use of goods and services is associated with monetary or any other considerations. Subscriptions, licensing fees, pay-per-view fees are current price barriers in scholarly publishing.

3) Permission barriers: These arise when the access to and the use of goods and services is fully or partially inhibited by legal regulations which specify manners and purposes of their utilization.

Herb (cf. 2015: 10-15) has already pointed out that openness is differently defined within the scientific community, where OA still means the removal of pay barriers for research output only. The accessibility to other information items like primary research data and software implemented for purposes of research is hardly ever granted. Scholars thus essentially content themselves with the definition of openness proposed by the BOAI (2001) that, according to Herb (2012: 11; 2015: 23), satisfies "minimum requirements" only. That is why he recommends the consistent terminological and conceptual distinction between "free" or "gratis" and "open" information items (cf. Herb 2015: 31-34). As we refer to the accessibility of scientific results only and not to their unrestricted re-use, we will subsequently work with the conventional proposition formulated as follows by Björk et al. (2013: 237): "literature that is merely free without granting liberal re-usage rights is still considered OA". Peter Suber, one of the best-known advocates of OA publishing, calls this kind of texts "royalty-free literature" and refers to them as very "low-hanging fruit of OA" (cf. Suber n.d.).

\section{Open Access and the Research Cycle}

At this point it is necessary to return to a chart of the research cycle as previously outlined by Agnetta (2015: 14-28). This description of research workflow will be completed with an analysis of the contemporary research and publication landscape in translatology. For this purpose a corpus of 115 explicit translation-related scientific journals (translating, interpreting or both) from all around the world and dating from 1995 until now has been compiled in order to examine whether and to what extent they conform to the OA principle (see Annex 1).

Academic activity of (comparative) philologists can be described as three successive and repeating phases: A. Research in a narrower sense, B. publication and $\mathrm{C}$. the subsequent use of the generated or worked up knowledge. There is no categorical rejection of the OA principle in 
contemporary humanities, as Agnetta has shown (cf. 2015: 13-14, 23). For scholars in the humanities already do make full use of all the benefits which go along with OA in the research paradigm (A.) (listed for instance in Fröhlich 1998: 545). Below we will follow up the extent to which the OA maxim is accepted in all of the above mentioned phases.

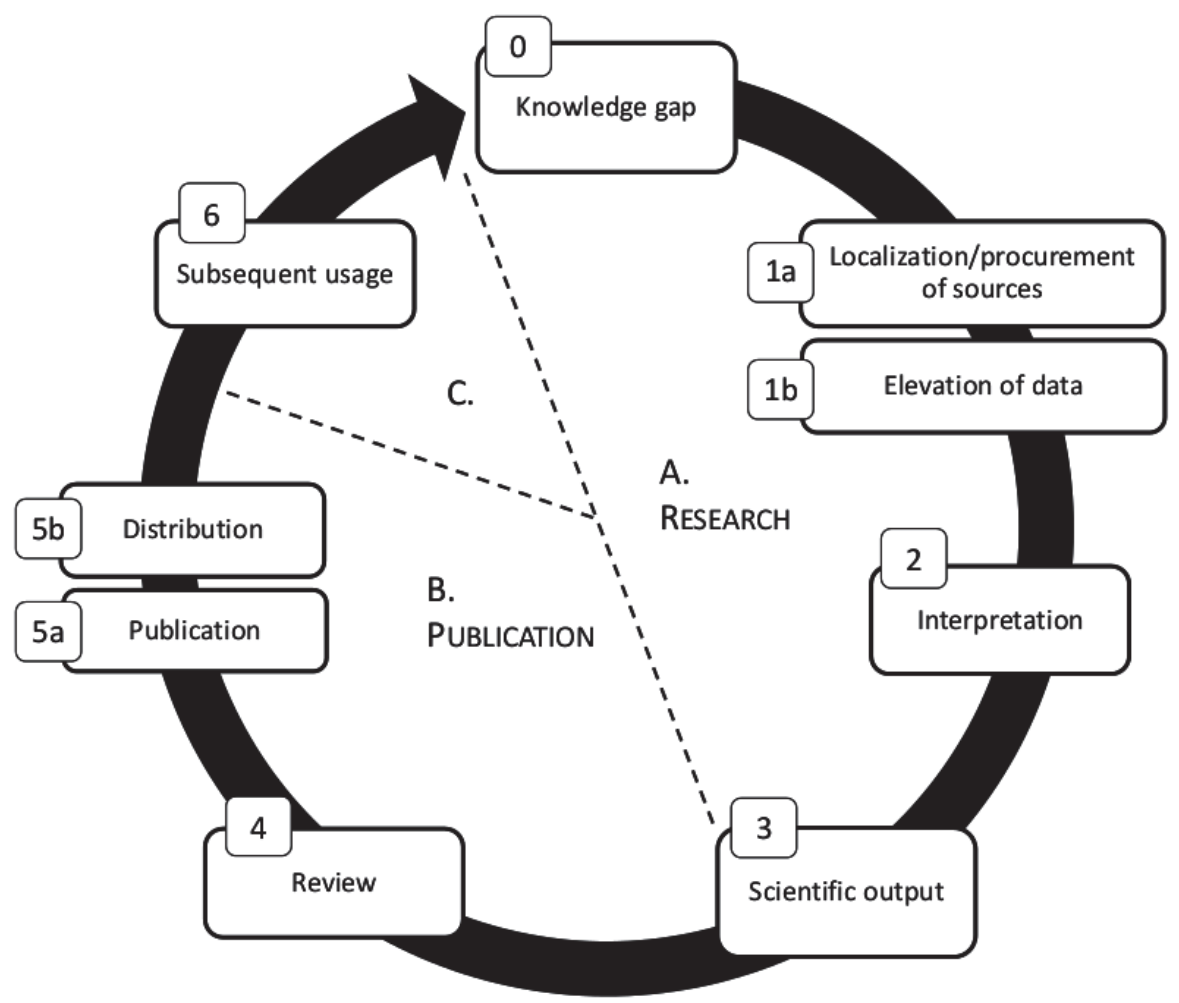

Figure 1: Research and publication workflow (Source: Agnetta 2015: 15).

(0) The research and publication workflow may be further divided into six single stations. It finds its starting point in the identification of a knowledge gap by one or more scholars while they are working with existent knowledge sources (be it printed or web media). It may be claimed that the more information is available without restrictions the more efficiently further knowledge gaps can be detected. 
(1) With the aim of filling this knowledge gap, the philologist initiates his research including the localization and procurement of the sources (1a) and the acquisition of primary data (1b).

(1a) Localization and procurement of the sources: Online bibliographies, databases, and abstract services provide scholars with instruments which are presently indispensable for the localization of existing relevant literature and data. Those which can be fully or partially accessed in the Web can be located by means of certain Web services like Google Scholar or the Bielefeld Academic Search Engine (BASE). At best, these can be downloaded and printed as needed. Adema and Ferwerda (2009) debate whether OA makes sense for the publication of monographs which still dominate the humanities and social sciences ant they conclude that OA could "be a good alternative" (2009: 179) to conventional print publishing if determinate factors are taken into consideration. For the historical branches of translatology it is also one of the major goals that sources, at least those which are not protected by copyright, are available in digital scans or copies.

(1b) Elevation and procurement of the primary data: The success of many of the empirically working branches of Translation Studies depend on the availability of possibly already annotated corpora. Since their compilation is generally extremely time consuming and labor intensive, listings of searchable and possibly even workable corpora which include information about their free/open availability are of ever-increasing importance. This is one of the tasks of those centers of the Clarin-D consortium (Clarin-D n.d.) focusing mainly on (applied or comparative) linguistics as does for instance the Hamburg Center for language corpora (HZSK n.d.). Overviews over translatologically exploitable corpora are given for example in Possamai (2009) and Pontrandolfo (2012). In a research field with such an interdisciplinary orientation it is furthermore not negligible to which extent research results and data of neighboring disciplines are made available to Translatology.

(2) Interpretation: When primary and secondary sources have been procured they require quantitative and qualitative analysis. Here again institutions like Clarin-D provide corpus-based Translatology with infrastructures, tools and annotation criteria. According to the guidelines of the undermentioned CClicensing, annotation is not included among those "derivates" that can be prohibited by the CC-ND-license (cf. Herb 2015: 20-21).

(3) Scientific output: On the basis of the sources' interpretation researchers put down in writing their results. In Translatology, monographs, contributions to collected volumes (in the form of conference papers and jubilee 
publications), and to an increasing extent also journal articles are customary. In the humanities, where individual authorship remains the dominant mode of publishing, it is not usual to publish unfinished texts. Proofreading, exchange of views and quality control take place before formal publication. The dissemination of preprints is rarely found in these disciplines.

(4) Review: Journal articles and contributions to collected volumes generally pass through a multi-step reviewing procedure, in the course of which expert judgements are asked by the responsible editors. In the case of monographs, it is the post-publication recension that functions as equivalent "controlling instance" (Schütte ${ }^{2} 2009$ : 3). In the rest of the cases, pre-publication reviews ought to assure quality of the final and publishable manuscript. But it is precisely these reviewing procedures that are always accused of offering great manipulative potential because of the lack of transparency.

Herb (2010: 6ff.; 2012: 21-28; 2015: 169-195) discusses how far reviewing procedures should be made transparent for the whole scientific community by explaining new concepts of collaborative and open reviewing. Open reviews that name reviewer and reviewed scholar carry the risk of public humiliation of the latter since possible rejections would not only be visible, but also countable and finally evaluable. In the meantime, there are voices advocating at least a numerical publication and evaluation of generated reviews which are still not appreciated in common academic praxis, neither financially nor in terms of reputation. One initial approach to this purpose is presented by the website Publons.com (n.d.) that offers reviewers a platform to record their peer review contributions without breaking reviewer anonymity.

(5) Publication and distribution: After these multi-step quality assurance procedures the reviewed manuscript is sent to the publisher that has been commissioned for the formal publication (5a) and the distribution of printed or digital copies (5b).

(5a) Publication: The publishing landscape in translatology has significantly changed in the past two decades. Monographs (possibly in the form of doctoral or postdoctoral theses) and collected books find equal publication formats in the numerous OA journals. The online Directory of Open Access Journals (DOAJ) that compiles - albeit with some time lag peer-reviewed OA journals from all over the world lists only two OA journals under the rubric "Translating and Interpreting" (as of August 2015). One more accurate search on the websites of the German electronic journals database (EZB n.d.) and Hispanic database dialnet (n.d.) provides a more comprehensive picture of existing translatological journals and their accessibility on the web: 


\begin{tabular}{|l|r|c|c|}
\hline Type & \multicolumn{1}{|c|}{$\begin{array}{c}\text { Total } \\
\text { (in \%) }\end{array}$} & $\begin{array}{c}\text { founded before 2000 } \\
\text { (journals before 2000) }\end{array}$ & $\begin{array}{c}\text { founded between } \\
2000 \text { and 2014 }\end{array}$ \\
\hline Total & $115(=100 \%)$ & $(47)$ & 68 \\
\hline OA & $78(\approx 68 \%)$ & $(22)$ & 56 \\
\hline OA with restrictions & $12(\approx 2 \%)$ & 10 & 2 \\
\hline non-OA & $25(\approx 30 \%)$ & 15 & 10 \\
\hline
\end{tabular}

Table 1: Journals in translatology.

This search yields a total number of 115 translatological journals published during the period between 1995 and 2014. Often it is no longer possible to reconstruct from which year certain print journals extended their offer by digitizing previous issues or by switching completely to OA publishing. Dates in brackets therefore do not necessarily refer to the publication type of a journal when it was established but rather to whether issues of those years are freely accessible from today's point of view. OA journals "with restrictions" are those restricting immediate open accessibility by any kind of non-disclosure notice or blocking period. All data given represents a snapshot dating August 2015.

Since 2000 not less than 56 translatological OA journals have been founded. And it should also be borne in mind that journals of related disciplines which could not be taken into account here provide a publishing platform for translation scholars as well. Foundations of journals which are not purely OA decrease more or less significantly after 2000 . So it can be observed that more than two thirds of all existing translatological journals follow the OA maxim in 2015.

The question remains open whether authors are allowed to retroactively archive their printed articles in OA repositories (green road of OA publishing). According to information from the SHERPA/RoMEO database most of the publishers of non-OA journals only allow self-archiving or publishing of preprints or not copy-edited article versions which thus cannot be cited precisely. For journals which do not exist in this database (cf. column "not specified") it can be assumed that self-archiving is not welcomed either. 


\begin{tabular}{|c|c|c|c|c|}
\hline Archiving & Total & $\begin{array}{c}\text { green publishing } \\
\text { (not publisher's } \\
\text { version) }\end{array}$ & $\begin{array}{c}\text { yellow publishing } \\
\text { (only pre-prints) }\end{array}$ & $\begin{array}{c}\text { not specified } \\
\text { (no self-archiving) }\end{array}$ \\
\hline $\begin{array}{c}\text { OA with } \\
\text { restrictions }\end{array}$ & 12 & 5 & 0 & 7 \\
\hline non-OA & 25 & 7 & 1 & 17 \\
\hline
\end{tabular}

Table 2: Self-publishing/archiving of articles in translatological journals

In the meantime many research institutes and research funders comply with the OA maxim and predicate financing on the condition that projectrelated publications should be made accessible in OA (cf. Herb 2015: 5458). Detailed listings of such institutes and funders that have committed themselves to OA and which are mostly at the same time signatories of the above mentioned manifestos (BOAl, Berliner Erklärung) is provided by the SHERPA/JULIET database. According to this website, OA is - in Germany - explicitly encouraged or demanded in the publication guidelines of the German Research Foundation (DFG n.d.), the Fraunhofer-Gesellschaft and the Helmholtz Association of German Research Centres. These mandate the OA publication of research output (in the form of peerreviewed original articles) and, in certain cases, even of primary research data (at the DFG). Free accessibility in appropriate repositories or the institute's own e-libraries (e.g. Fraunhofer e-Prints) is to be ensured as soon as possible, if need be when an imposed embargo period of six to eighteen months expires. However, important German research institutes and funders, even those which have decisively promoted the OA movement in Germany, have been omitted in this database, as has the Max Planck Society (n.d.) and the Leibniz Association (n.d.).

(5b) Distribution: More and more frequently researchers complain that most publishers merely seek to make a profit from the researchers' many years of work. Presently seen as mere money machines, publishers seem to have moved away from their original function of ensuring access to high quality research. Occasionally one can find extreme cases in which the content of volumes put on the market does not play any role if title and author (team) promise high turnovers. Assertions such as that quality is to be assured by publishers do not reflect reality - at least, not in the humanities. In the majority of cases, it is the authors themselves or the unpaid reviewers who bear responsibility for ensuring the absence of errors of content and form and who worry about editing and layout. Nevertheless, there is no need to condemn all existing publishers, since 
several of them are beginning to extend their offerings by also establishing OA series.

However, it is important to mention that, especially in the case of OA journals conceived as such from the outset (golden road of OA publishing), costs are shifted from the recipient's to the producer's side, which means that author and potential funders now pay for publishing. The problem of social disadvantage frequently referred to in open OA discourse is now reproduced on the author's side: Whoever has the most money, publishes most. Alternative funding possibilities are described in Herb (2015: 60-82).

(6) Subsequent usage: Many entities are interested in the continued use of published research results, whether for again scientific, economic or simply individual information needs. It is undoubtedly a great achievement for OA movement that authors are able to retain the rights to the produced output as their intellectual property and to determine by themselves its further utilization. In recent times, Creative Commons Licenses (n.d.), which guarantee the naming of the author who has produced or elaborated the available contents (CC-BY), have become widespread in specifying the legal framework of subsequent usage of research results on the Web. In conventional publication workflows researchers were required to renounce their rights, ceding them to the publishing house they had chosen. Only a few publishers cede to the authors the right to archive their scientific output - after an embargo period of twelve to eighteen months from print publication - in appropriate repositories. In any case authors have to claim the contractual termination of such permission.

However, one fact in OA publishing is still considered a serious problem and that is the long-term availability of digital objects, which is regarded as insufficient among many web users, researchers included. The above mentioned time barrier is cited here. In any case, there are several approaches for its removal. One of them consists in the open source system LOCKSS (Lots Of Copies Keep Stuff Safe, n.d.) which ensures the long-term preservation of digital contents by means of their sevenfold storage in locally separated and hard drives (LOCKSS boxes) distributed all over the world. This prevents information loss in the case one or more hard drives fail. Questions concerning one binding standard electronic format for scientific results, as requested by the Berlin Declaration (2003), still remain unresolved.

\section{Open Access and Academic Practice}

Up to here our statements have been contingent on one condition whose fulfillment cannot be assumed flatly among scientists: The researcher does 
support OA! Some barriers to research results are involuntarily or not least voluntarily created by scholars to protect themselves from present-day hostile academic mechanisms.

\subsection{Open Access in University Education}

An unsatisfactory system at universities for raising the level of awareness concerning publication possibilities and alternatives can be considered one of the involuntarily existing barriers to open accessibility. It may thus be argued that there is a genuine need for awareness campaigns.

We may assume that future translatologists first come into contact with the discipline during their time at university and that one of their first publishing experiences is the publication of a university thesis. A study attempting to explore how far the opportunity for OA publishing is available to German translatologists from the outset of their career should therefore commence with higher education institutes.

An in-depth analysis of the repository landscape in the German-speaking area is provided by the "2014 Census of Open Access Repositories in Germany, Austria and Switzerland" (cf. Vierkant/Kindling 2014). This statistical survey reveals that $42.01 \%$ of all universities (artistic higher education institutes included) and $9.38 \%$ of all technical colleges on German territory do operate OA repositories. In this context, the Göttingen State and University Library (SUB Göttingen) deserves particular mention due to the fact that this institution has committed itself to the setting up and maintenance of digital research environments and research infrastructures for data and services.

In the following it has to be established whether (young) German translatologists have the opportunity to publish their theses (BA, MA, doctoral and postdoctoral theses) in such repositories. Therefore, all state universities have to be listed, at least in terms of numbers, in which studies in translatology can be taken up. In a relevant German manual (Handbuch der Universitäten und Fachhochschulen, HUF ${ }^{22}$ 2012), seven universities and technical colleges are listed under the search items "translatology" and "interpretation/translation". This listing has been updated and complemented through our own investigation (see Annex 2). Half of the total of fourteen identified higher education institutes offer the opportunity to pursue a doctorate or habilitation. With the aid of the online Registry of Open Access Repositories (ROAR, n.d.) and our own web search it was possible to verify whether the respective education institution operates a publication server and/or OA publisher of its own. 13 of the 14 higher education institutions offer the possibility of OA publication of at least doctoral theses; the only exception is one technical college. If we refer to the above mentioned Census (2014), this result corresponds to the normal 
case. It therefore can be proved that young translatologists of nearly all higher education institutions in Germany have the opportunity of OA publication.

But a broader awareness campaign still remains desirable. OA publication as an alternative to conventional book publishing could be explicitly integrated in examination, doctorate, and habilitation regulations in the humanities. In this regard, initiatives of three German universities play a pioneering role: These are on the one hand the cooperation program MAP - Modern Academic Publishing (n.d.) between the universities of Cologne and Munich and on the other the OA publisher of Saarland University universaar (n.d.).

Congress organizers could also be strongly encouraged to support OA publishing of the collected conference papers. One example of this may be the EU-financed translatological conference series on "Multidimensional Translation - MuTra" held in Saarbrücken (2005), Copenhagen (2006), and Vienna (2007), whose proceedings are entirely available on the Web. All of the OA publishing researchers have furthermore the choice to let their works (to which they retain all rights) be printed and marked by external and independent print-on-demand service providers like Monsenstein und Vannerdat or Epubli. Such hybrid publication models will surely become increasingly attractive in the future.

\subsection{Academic Practice, Scientometrics and Open Access}

Answers to the question whether OA and Open Science are largely accepted within the scientific community must necessarily take into account the structures and functioning of university career paths (cf. Agnetta 2015: 13). One could suppose that younger researchers support OA rather than established scholars since the former are often more technophilic and call into question the strict hierarchical academic structures. But this is not the case in times like these.

Anyone who imprudently publicizes Open Science as a common ideal will quickly be confronted with the utopian character of such a perspective. Even if Suber (2015) proves that "to advance knowledge does not conflict with the strong self-interest in career-building", it may be argued that OA to and altruistic provision of information seems to be undesired wherever research results promote academic or economic competitiveness. Non-disclosure notices specified by clients from economy and politics and the voluntary shortage or detention of research data by academic actors are no surprise within a context of competitive thinking and performance pressure. This concerns the humanities as much as the natural sciences. The massive budgetary cutbacks recently recorded across Germany are surely not welcome in this respect either. 
Job offerings, involvement in projects, etc., depend more and more on questionable performance measurements that consider only publication activity and third-party fundraising disregarding other academic activities, teaching above all. Therefore, it is no surprise that research and publishing activity of scholars results partially from extrinsically motivated decisions, which means that they are not immediately related to the purpose of scientific progression (cf. Merton 1988: 621). That is why philosophers of science like Fröhlich call into question the intention of scientists to communicate optimally with their colleagues. He proves that retention, blockage, and retardation of information are current "effective strategies" even in the same research institution (cf. Fröhlich 1998: 536). If, on the other hand, proponents of OA accuse scientist of ignoring OA discourse within their own research, it may be replied that for many researchers this would mean a further distraction from the own research interest.

And thus emerges the quite paradoxical situation in which younger researchers have less interest in the open and free accessibility of their research results than established senior researchers. Thereby we want to address the importance of central institutions, whose task should be to provide, preserve and optimize functioning infrastructures for science in continuous consultation and cooperation with researchers.

Fröhlich (1998: 544ss.) paints a sobering picture: OA principle and web communication hold the potential to democratize science. But changing the problematic issues we have just touched on is not inevitably connected to changing the medium of publication. Existing problems will not suddenly be abolished if scholarship shifts to OA publishing. In truth, cases will continue to exist in which OA research infrastructure proves to be as vulnerable to abuse as conventional print models were (currently in Spain: cf. Sánchez Perona 2015 and Aréchaga n.d.). The OA system has also been successfully challenged by provocative researchers (cf. scholarlyoa.com n.d. and SClgen n.d.). A gift economy based on reciprocity can be set up on the web as well as in non-web-based research environments by replacing mutual citation with interlinking for example (cf. Fröhlich 1998: 539-40).

It remains, thus, questionable whether in the future platforms will prevail which explicitly claim a return to research ethics and which offer scholars an environment in which they can do their research detached from extrinsic considerations, as the website www.sjscience.org holds out the prospect of.

\subsection{Linguistic Diversity as Symptom of Research Diversity}

There is general acknowledgement that all communication in the (natural) sciences should not be culture-specific, and the humanities also basically 
endeavor to achieve intersubjectivity and intercomprehensibility. In view of the continuing internationalization of science there is one implicit request scholars feel themselves confronted with: It consists in the fact that they have to publish their works in English in the interests of increased visibility.

This may not be seen as problematic by OA supporters since a binding use of English as the lingua franca of science would mean the removal of an additional barrier to knowledge resources: that of the language. It need not be explained that English appears best-suited to take on the function of language of science by virtue of the number of (non-native) speakers. There are also linguistic peculiarities of English such as its practicability and simpler learnability that definitely suggest its use as common language in science (cf. Stackelberg 1988/2009: 5).

However, particularly in the philologies, in comparative linguistics, and translatology such demands cause a lot of contention. For many philologists equate research diversity with language diversity. It is in this spirit that Jürgen von Stackelberg, German Romance philologist and comparatist, defends the fact that scholars only meet the requirements of the own research subject when they draft their research results in their native language (cf. Stackelberg 1988/2009: 22). He views this trend towards making scientific research solely available in English as extrinsically motivated behavior on the part of researchers: "Humanists do, therefore, obey 'external' constraints. There are other than science immanent reasons when they publish in English" (ibid.: 10, translation: M.A.).

English is the most widely represented language in the submissions guidelines of the journals of our corpus (see Table 3). Other "major" languages are accepted in less than $50 \%$ of cases, but at the same time the percentage of pure OA journals is much higher in these languages than in English.

\begin{tabular}{|l|c|c|c|c|}
\hline $\begin{array}{c}\text { Total } \\
\text { 115 Journals }\end{array}$ & $\begin{array}{c}\text { Total } \\
\text { (language) }\end{array}$ & $\begin{array}{c}\text { \% } \\
\text { of Total }\end{array}$ & $\begin{array}{c}\text { OA } \\
\text { (in \%) }\end{array}$ & $\begin{array}{c}\text { not/partially OA } \\
\text { (in \%) }\end{array}$ \\
\hline English & 96 & $83 \%$ & $65(68 \%)$ & $31(32 \%)$ \\
\hline French & 47 & $41 \%$ & $40(85 \%)$ & $7(15 \%)$ \\
\hline Spanish & 45 & $39 \%$ & $37(82 \%)$ & $8(18 \%)$ \\
\hline German & 23 & $20 \%$ & $19(83 \%)$ & $4(17 \%)$ \\
\hline Portuguese & 20 & $17 \%$ & $20(100 \%)$ & $0(0 \%)$ \\
\hline Italian & 17 & $15 \%$ & $15(88 \%)$ & $2(12 \%)$ \\
\hline Catalan & 8 & $7 \%$ & $8(100 \%)$ & $0(0 \%)$ \\
\hline Serbian & 3 & $3 \%$ & $3(100 \%)$ & $0(0 \%)$ \\
\hline
\end{tabular}




\begin{tabular}{|l|c|c|c|c|}
\hline $\begin{array}{c}\text { Total } \\
\text { 115 Journals }\end{array}$ & $\begin{array}{c}\text { Total } \\
\text { (language) }\end{array}$ & $\begin{array}{c}\% \\
\text { of Total }\end{array}$ & $\begin{array}{c}\text { OA } \\
\text { (in \%) }\end{array}$ & $\begin{array}{c}\text { not/partially OA } \\
\text { (in \%) }\end{array}$ \\
\hline Chinese & 2 & $2 \%$ & $1(50 \%)$ & $1(50 \%)$ \\
\hline Russian & 2 & $2 \%$ & $1(50 \%)$ & $1(50 \%)$ \\
\hline Dutch & 1 & $<1 \%$ & $1(100 \%)$ & $0(0 \%)$ \\
\hline Galician & 1 & $<1 \%$ & $1(100 \%)$ & $0(0 \%)$ \\
\hline Japanese & 1 & $<1 \%$ & $0(0 \%)$ & $1(100 \%)$ \\
\hline Korean & 1 & $<1 \%$ & $0(0 \%)$ & $1(100 \%)$ \\
\hline Norwegian & 1 & $<1 \%$ & $1(100 \%)$ & $0(0 \%)$ \\
\hline Polish & 1 & $<1 \%$ & $0(0 \%)$ & $1(100 \%)$ \\
\hline Romanian & 1 & $<1 \%$ & $1(100 \%)$ & $0(0 \%)$ \\
\hline X: language not specified or 'further languages': 5-4\%-4 & \\
\hline
\end{tabular}

Table 3: Languages in translatological journals.

Even though it is clear that what Stackelberg says results from a deep but individual conviction and one can find only few rational points in his argumentation, such statements bear witness to the great reservations many other philologists express with respect to anglicization of science language. Such voices are becoming loud in other countries, too, as is happening in Italy and France. In an issue of the French magazine Circuit - Le magazine d'information des langagiers (41/September 1993) that focuses on this topic (Title: L'Europe au rythme de l'anglais) Cormier/Humbley (1993: 2) worriedly observe that $80 \%$ of all scientific texts are already drafted in English (cf. also the satirical contribution "How did science come to speak only English" by Michael D. Gordin 2015). That communication and cooperation across borders is essential for research is in no case disputed by humanities scholars. But many of them agree that the binding use of English as the only one "langue véhiculaire" (Cormier/Humbley 1993: 2) is appropriate for texts of mere administrative character (reports and announcements for instance) or for the overwhelming majority of publications in the natural sciences but it is undesired in humanities and arts (cf. Stackelberg 1988/2009: 5, 11).

One might accuse Stackelberg of having a naive view of language when he suggests that institutions could impose the use of one common language on researchers. After all, language history proves impressively that normative language imposition is always shattered sooner or later. According to Stackelberg (1988/2009: 7) the intention to implement the use of a common language in science would, therefore, be an anachronism. And yet the 
reservations formulated by the not primarily anglophone scientific community are not entirely unfounded.

In those disciplines in which quantifiable indicators are supposed to give information about research quality the use of English becomes, even if not explicitly stated, a necessary precondition for being noticed and cited outside the confined national borders. Besides third-party fundraising, citation remains the most important indicator for performance evaluation in research. The French anglicist Pierre Truchot (1993: 7) gets to the heart of the matter by formulating: "l'anglais ou l'anonymat" (English or anonymity). The demand for international comparability and the scientometrical analyses presently perform the function of a language standardizing institution.

So it is no wonder that journals of non-anglophone countries almost exclusively publish articles in English, as does the German OA journal TC3 Translation: Computation, Corpora, Cognition. At least, one concession is made to the intrinsic multilingualism of translatology when "one paper per issue which is written in a language other than English" is accepted.

The preference for English submissions, abstracts and data mining is justified by the increased visibility of the scientific output. However, this is not the only reason. The translatological OA journal Hermēneus (n.d.) that accepts at least five languages apologizes to the submitters of differing linguistic skills that "experts with the proper linguistic competence and knowledge in pertinent fields in languages other than those mentioned are not often available to evaluate articles". In a young discipline such as translatology which has numerically far fewer scholars than other sciences, availability of experts that allow quality assurance of contributions in the minor language simply cannot be guaranteed.

We thus agree with Stackelberg (1988/2009: 4, 22) when he notes that the true removal of language barriers can only be initiated by means of translations. Also the OA journal from our corpus, $452^{\circ} \mathrm{F}$ : The Journal of Literary Theory and Comparative Literature agrees with this view by committing itself to multilingualism, to "[s]atisfy the need of a multilingual world: relying on the intrinsic cultural value of linguistic diversity, together with the need to reach as many readers as possible, several linguistic barriers will be avoided" ( $452^{\circ} \mathrm{F}$ n.d.).

Good translation of reliable scientific literature might in future meet with the same academic appreciation as recensions and the preparation of didactic literature on the subject currently do. Anglophone research has already recognized this fact, as one can see from the language policies of the OA journal Metamorphoses: A Journal of Literary Translation that take "as its mission the publication of quality English language translation of the most 
interesting articles [...] presently available only in their source language" (n.d.). The Hispanic journal MonTI - Monografias de Traduccion e Interpretacion accepts translations to all minor languages in the online edition and tries to provide English versions of all submitted articles.

\section{Conclusions}

Research in the humanities and especially in translatology is still far from being part of an "Open Research Web" which is portrayed as a worthwhile goal by Shadbolt et al. (2006). This is only partially due to the not fully developed infrastructures which could ensure open access to all information items that accrue in the course of the research and publication workflow. For the way has definitely been already marked out. In fact, slow development in this direction results from manifold and partially competing economic, scientific-political and individual interests pursued by authors, users, research institutions, publishers and more.

The presented discipline-specific analysis demonstrates that translatology is no straggler in the matter of open accessibility and that it has already internalized many issues of the OA movement. The sharp increase of translatological OA journals, the availability of linguistic primary data and corpora on the Web as well as the possibility of OA publishing at nearly all tertiary education institutions which offer courses of translation studies testify to a drive for innovation in our discipline. Here hybrid models that equally provide for printed and online versions of contents legitimately predominate in the publication landscape of translatology.

\section{References}

$452^{\circ} \mathrm{F}$ (n.d.) The Journal of Literary Theory and Comparative Literature Available at: http://452f.com/index.php/en/entidad-editora12 [Accessed August 2015].

Adema, J. and Ferwerda, E. (2009) Open Access for Monographs. LOGOS: The Journal of the World Book Community 20/1, 176-183. DOI: 10.1163/ $095796509 \times 12777334632708$.

Agnetta, M. (2015) Technik, die begeistert?! Zur Open-Access-Debatte in der heutigen Sprach- und Translationswissenschaft. In C. Polzin-Haumann and A. Gil (eds.) Angewandte Romanistische Linguistik. Kommunikations- und Diskursformen im 21. Jahrhundert. St. Ingbert: Röhrig Universitätsverlag, 11-28.

Aréchaga, J. (n.d.) Open Access, un arma de doble filo para las revistas científicas. Available at: http://www.sebbm.com/revista/articulo.asp?id=10007\&catgrupo=265\& tipocom=24 [Accessed August 2015].

Aschenbrenner, A., Blanke, T., Dunn, S., Kerzel, M., Rapp, A. and Zielinski, A. (2007) Von e-Science zu e-Humanities - Digital vernetzte Wissenschaft als neuer Arbeits- und 
Kreativbereich für Kunst und Kultur. Bibliothek. Forschung und Praxis 31/1, 11-21. DOI: 10.1515/BFUP.2007.11.

BASE (n.d.) Available at: http://de.base-search.net [Accessed August 2015].

Berlin Declaration 2003 Available at: www.openaccess.mpg.de/Berliner-Erklaerung [Accessed August 2015].

Björk, B., Laakso, M., Welling, P. and Paetau, P. (2014) Anatomy of green open access. Journal of the Association for Information Science and Technology 65/2, 237-250. DOI: 10.1002/asi.22963.

BOAI 2001 Available at: www.budapestopenaccessinitiative.org [Accessed August 2015].

Clarin-D. (n.d.) Available at: http://www.clarin-d.de/en/home [Accessed August 2015].

Cormier, M. and Humbley, J. (1993) L'anglais en Europe: la croisée des Chemins. Circuit. Magazine d'information sur la langue et la communication 41, 2. Available at: http://www.circuitmagazine.org/images/stories/documents/archives/Cl_41_93.pdf.

Creative Commons Licenses (n.d.) Available at: http://creativecommons.org) [Accessed August 2015].

DFG (n.d.) Available at: http://www.dfg.de/en/research_funding/programmes/infrastructure/ lis/funding_opportunities/open_access_publishing/index.html [Accessed August 2015].

Dialnet (n.d.) Available at: http://dialnet.unirioja.es [Accessed August 2015].

DOAJ (n.d.) Available at: https://doaj.org/ [Accessed August 2015].

EZB (n.d.) Available at: http://rzblx1.uni-regensburg.de/ezeit [Accessed August 2015].

Fröhlich, G. (1998) Optimale Informationsvorenthaltung als Strategem wissenschaftlicher Kommunikation. In Zimmermann, H. and Schramm, V. (eds.) Knowledge Management und Kommunikationssys-teme, Workflow Management, Multimedia, Knowledge Transfer. Proceedings of the 6. Internationalen Symposium on Information Science (ISI 1998), Prague, 3.-7. November 1998. Konstanz: UVK Verlagsgesellschaft mbH, 535549.

Gordin, M. (2015) Science once communicated in a polyglot of tongues, but now English rules alone. How did this happen - and at what cost? Available at: http://aeon.co/ magazine/science/how-did-science-come-to-speak-only-english/ [Accessed August 2015].

Herb, U. (2012) Offenheit und wissenschaftliche Werke: Open Access, Open Review, Open Metrics, Open Science \& Open Knowledge. In Herb, U. (ed.) Open Initiatives: Offenheit in der digitalen Welt und Wissenschaft. Saarbrücken: universaar, 11-44. Available at: http://universaar.uni-saarland.de/monographien/volltexte/2012/87/ [Accessed August 2015].

Herb, U. (2015) Open Science in der Soziologie: Eine interdisziplinäre Bestandsaufnahme zur offenen Wissenschaft und eine Untersuchung ihrer Verbreitung in der Soziologie. Glückstadt: Verlag Werner Hülsbusch. DOI: 10.5281/zenodo.31234.

Hermēneus (n.d.) Available at: http://www5.uva.es/hermeneus/?p=254\&lang=en) [Accessed August 2015].

HUF (22012) Handbuch der Universitäten und Fachhochschulen. Deutschland, Österreich, Schweiz. Berlin, New York: De Gruyter Saur.

HZSK (n.d.) Available at: https://corpora.uni-hamburg.de/drupal [Accessed August 2015]. 
Leibniz Assotiation (n.d.) Available at: http://www.leibniz-gemeinschaft.de/infrastrukturen/ open-access [Accessed August 2015].

LOCKSS (n.d.) Available at: http://www.lockss.org [Accessed August 2015].

MAP (n.d.) Available at: http://www.humanities-map.net [Accessed August 2015].

Max Planck Society (n.d.) Available at: http://openaccess.mpg.de [Accessed August 2015].

Merton, R. K. (1988) The Matthew Effect in Science II - Cumulative Advantage and the Symbolism of Intellectual Property. ISIS, 79, 606-623.

Metamorphoses (n.d.) Available at: http://www.artintranslation.org/ [Accessed August 2015].

MonTI (n.d.) Available at: http://dti.ua.es/es/monti/monti.html [Accessed August 2015].

MuTra 2005-2007: Available at: http://www.euroconferences.info/proceedings/ proceedings.php?proceedings=1) [Accessed August 2015].

OKFN (n.d.) Available at: www.okfn.org/opendata [Accessed August 2015].

Opendefinition (n.d.) Available at: www.opendefinition.org/od [Accessed August 2015].

Pontrandolfo, G. (2012) Legal Corpora: an overview. Rivista Internazionale di Tecnica della Traduzione 14, 121-136. Available at: http://hdl.handle.net/10077/9783 [Accessed August 2015].

Possamai, V. (2009) Catalogue of Free-Access Translation-Related Corpora. Revista Tradumàtica 7/2009. Available at: http://www.fti.uab.cat/tradumatica/revista/num7/ articles/09/9art.htm

Publons.com (n.d.) Available at: https://publons.com [Accessed August 2015].

ROAR (n.d.) Available at: http://roar.eprints.org/ [Accessed August 2015].

ROARMAP (n.d.) Available at: http://roarmap.eprints.org [Accessed August 2015].

Sánchez Perona, J. (2015) La peligrosa deriva de las publicaciones en acceso abierto. Available at: http://cienciaconfuturo.com/2015/07/23/la-peligrosa-deriva-de-laspublicaciones-en-acceso-abierto/ [Accessed August 2015].

scholarlyoa.com (n.d.) Available at: http://scholarlyoa.com/2014/11/20/bogus-journalaccepts-profanity-laced-anti-spam-paper [Accessed August 2015].

Schütte, G. ('2009) Zählen, gewichten, lesen. Zur Bewertung von wissenschaftlichen Publikationsleistungen in Peer review-Prozessen. In Alexander von Humboldt-Stiftung (ed.) Publikationsverhalten in unterschiedlichen wissenschaftlichen Disziplinen. Beiträge zur Beurteilung von Forschungsleistungen, 212/2009, 3-4.

SClgen (n.d.) Available at: http://pdos.csail.mit.edu/scigen [Accessed August 2015].

Shadbolt, N., Brody, T., Carr, L. and Harnad, S. (2006) The Open Research Web: A Preview of the Optimal and the Inevitable. In N. Jacobs (ed.) Open Access: Key Strategic, Technical and Economic Aspects. Oxford: Chandos Publishing, 13-26. Available at: http://eprints.ecs.soton.ac.uk/12453/ [Accessed August 2015].

SHERPA/JULIET (n.d.) Available at: www.sherpa.ac.uk/juliet [Accessed August 2015].

SHERPA/RoMEO (n.d.) Available at: http://www.sherpa.ac.uk/romeo [Accessed August 2015]. 
Stackelberg, J. (1988/2009) Künftig nur noch Englisch? Ein Plädoyer für den Gebrauch der Muttersprache in den Geisteswissenschaften. Bonn: Romanistischer Verlag Jakob Hillen.

Suber, P. (2015) Open Access Overview. Focusing on open access to peer-reviewed research articles and their preprints. Available at: http://legacy.earlham.edu/ peters/ fos/overview.htm [Accessed August 2015].

Truchot, C. (1993) La communication scientifique en Europe : l'anglais ou l'anonymat. Circuit. Magazine d'information sur la langue et la communication, 7-8. Available at: http://www.circuitmagazine.org/images/stories/documents/archives/Cl_41_93.pdf [Accessed August 2015].

Universaar (n.d.) Available at: http://www.uni-saarland.de/campus/service-und-kultur/ medien-und-it-service/universaar.html [Accessed August 2015].

Vierkant, P. and Kindling, M. (2014) Welche Institutionen betreiben Open-AccessRepositorien in Deutschland? LIBREAS. Library Ideas. Available at: http://libreas.eu/ausgabe26/ 07vierkantkindling/ [Accessed August 2015]. 


\section{Annex 1: OA Journals in Translatology}

In the following we present our corpus of 115 explicit translation-related scientific journals (translating, interpreting or both) from all around the world and dating from 1995 until now. It has been compiled in order to examine whether and to what extent they conform to the OA principle.

1. 1611: Revista de Historia de la Traducción

2. $452^{\circ} \mathrm{F}$, The Journal of Literary Theory and Comparative Literature

3. Across Languages and Cultures

4. Alternative Francophone

5. Art in Translation

6. Asia Pacific Translation and Intercultural Studies

7. Babel

8. Babilónia: Revista Lusófona de Línguas, Culturas e Tradução

9. Between

10. Bulletin du CRATIL

11. Cadernos de Literatura em Tradução

12. Cadernos de Tradução

13. Circuit : Magazine d'Information sur la Langue et la Communication

14. Communication and Culture Online

15. Compilation and Translation Review

16. Computers and Translation

17. Confluências : Revista de Tradução Científica e Técnica

18. Critical Multilingualism Studies

19. Cultura e Tradução

20. Cultural Intertexts

21. Doletiana: Revista de Traducció, Literatura i Arts

22. Entreculturas

23. Estudios de Traducción

24. Eutomia : Journal of Literature and Linguistics

25. Forfatteren Oversetteren

26. Hermeneus: Revista de la Facultad de Traducción e Interpretación de Soria

27. Hieronymus complutensis. El mundo de la traducción

28. Hikma: Estudios de traducción
29. J-ELTS, International Journal of English Language and Translation Studies

30. In other words

31. Interculturalidad y traducción. Revista internacional

32. International Journal of Interpreter Education

33. Interpreting

34. In-Traduções. Revista do Programa de Pós-Graduação em Estudos da Tradução da UFSC

35. InTRAlinea : Online Translation Journal

36. JoSTrans: The Journal of specialised Translation

37. Journal of Applied Linguistics and Language Research

38. Journal of Interpretation Research

39. Journal of King Saud University Languages and Translation

40. Journal of Translation

41. Koiné. Quaderni di ricerca e didattica sulla traduzione e l'interpretazione

42. La Linterna del Traductor

43. L'Antenne Express

44. Lebende Sprachen

45. L'Écran Traduit

46. Linguaculture

47. Linguística : Revista de Estudos Linguísticos da Universidade do Porto

48. Linguistica Antverpiensia. New series. Themes in Translation Studies

49. Livius.Revista de estudios de traducción

50. Machine Translation

51. Machine Translation Review

52. Meta: Journal des Traducteurs

53. Metamorphoses: A Journal of Literary Translation 
54. Między Oryginałem a Przekładem

55. MonTi. Monografás de Traducción e Interpretación

56. Mutatis Mutandis. Revista Latinoamericana de Traducción

57. New Voices in Translation Studies

58. Norwich Papers

59. Língua - Revista Digital sobre Tradução

60. Onomázein : Revista de Lingüística, Filología y Traducción

61. Palimpsestes. Revue de Traduction

62. Panace@ [Panacea]: Boletín de Medicina y Traducción

63. Papers Lextra: Revista electrònica del Grup d'Estudis Dret i Traducció

64. Perspectives : Studies in Translatology

65. Philologia

66. Professional Communication and Translation Studies

67. Puentes: Hacia nuevas investigaciones en la mediación intercultural

68. Pusteblume. Journal of Translation

69. Quaderns: Revista de Traducció

70. Recherches et Travaux

71. Redit, Revista Electrónica de Didáctica de la Traducción y la Interpretación

72. Revista de Lingüística y Lenguas Aplicadas

73. Revista Tradumàtica : Traducció i Tecnologies de la Informació i la Comunicació

74. Rivista Internazionale di Tecnica della Traduzione

75. Saltana

76. Scientia Traductionis

77. Sendebar

78. Senez

79. Skopos : revista internacional de traducción e interpretación

80. Studii de gramatică contrastivă

81. T21N : Translation in Transition

82. Target

83. TC3 - Translation : Computation, Corpora, Cognition
84. TEXTconTEXT

85. The Bible Translator

86. The interpreter's Newsletter

87. The Journal of Interpretation

88. The Translator. Studies in Intercultural Communication

89. Ticontre: Teoria, Testo, Traduzione

90. Trabalhos em Lingüística Aplicada

91. Traces. A multilingual journal of cultural theory and translation

92. TradTerm

93. Tradução \& Comunicação : Revista Brasileira de Tradutores

94. Tradução em Revista

95. Traducción \& Comunicación

96. Traduction, Terminologie, Rédaction (TTR)

97. Traduire

98. Tradurre

99. Traduttologia

100. Trans : Revista de Traductología

101. Transfer. Revista Electrónica sobre Traducción e Interculturalidad

102. Trans-kom

103. Translation : A Transdisciplinary Journal

104. Translation and Interpreting

105. Translation and Interpreting Studies (TIS): The Journal of the American Translation and Interpreting Studies Association

106. Translation and Literature

107. Translation Journal: A Publication for Translators by Translators about Translators and Translation

108. Translation Review

109. Translation Spaces

110. Translation Studies

111. Translation Today

112. Translation Watch Quarterly: A Journal of Translation Standards Institute

113. Translationes

114. Two Lines - A Journal of Translation

115. Viceversa: Revista galega de traducción 


\section{Annex 2: OA in German State Universities}

In the following, all state universities have been listed, at least in terms of numbers, in which studies in translatology can be taken up. In the German manual (Handbuch der Universitäten und Fachhochschulen, ${ }^{22} 2012$ ), seven universities and technical colleges are listed under the search items "translatology" and "interpretation/translation".

1. Fachhochschule Köln: Fakultät für Informations- und Kommunikationswissenschaften; Institut für Translation und Mehrsprachige Kommunikation

Fachübersetzen (Englisch, Französisch, Spanisch), Konferenzdolmetschen (Englisch, Französisch, Spanisch)

Promotions- und Habilitationsmöglichkeit nicht gegeben

OA: Cologne Open Science (http://opus.bsz-bw.de/fhk); Fachrepositorium (Informationswissenschaft): PubLIS Cologne (http://publiscologne.fh-koeln.de/home)

2. Ruprecht-Karls-Universität Heidelberg: Philosophische Fakultät; Institut für Übersetzen und Dolmetschen (IÜD)

Übersetzungswissenschaft [B.A.] (Englisch, Französisch, Italienisch, Portugiesisch, Russisch Spanisch)

Translation Studies for Information Technologies [B.A.] (Englisch)

Übersetzungswissenschaft [M.A.] (Englisch, Französisch, Italienisch, Portugiesisch, Russisch Spanisch)

Konferenzdolmetschen [M.A.] (Englisch, Französisch, Italienisch, Japanisch, Portugiesisch, Russisch, Spanisch)

Promotions- und Habilitationsmöglichkeit gegeben

OA: HeiDok - Heidelberger Dokumentenserver (http://archiv.ub.uniheidelberg.de/volltextserver)

3. Universität Hildesheim: Fachbereich 3: Sprach- und Informationswissenschaften; Institut für Übersetzungswissenschaft und Fachkommunikation Internationale Kommunikation und Übersetzen [B.A.] (Englisch, Französisch, Spanisch)

Medientext und Medienübersetzung [M.A.] (Englisch, Französisch, Spanisch)

Promotions- und Habilitationsmöglichkeit gegeben

OA: HilDok - Publikationsserver der Universität Hildesheim (http://hildok.bsz-bw.de/home)

4. Universität Leipzig: Philologische Fakultät; Institut für Angewandte Linguistik und

Translatologie

Translation [B.A.] (Englisch, Französisch, Russisch, Spanisch)

Interkulturelle Kommunikation und Translation [B.A.] (Tschechisch-Deutsch)

Translatologie [M.A.] (Englisch, Französisch, Russisch, Spanisch)

Fachübersetzen [M.A.] (Arabisch, Deutsch)

Konferenzdolmetschen [M.A.] (Arabisch, Englisch, Französisch, Russisch, Spanisch)

Promotions- und Habilitationsmöglichkeit nicht gegeben

OA: Qucosa - Publikationsserver der Universität Leipzig (http://ul.qucosa.de/startseite) 
5. Hochschule Magdeburg-Stendal (Standort: Magdeburg): Fachbereich Kommunikation und Medien, Internationale Fachkommunikation und Übersetzen [B.A.] (Deutsch, Englisch) Dolmetschen und Übersetzen für Gerichte und Behörden [Zertifikat, 2 Sem.] (je nach Nachfrage)

Promotions- und Habilitationsmöglichkeit nicht gegeben

OA: Digitale Hochschulbibliothek Sachsen-Anhalt [Universitätszusammenschluss] (https://www.hs-magdeburg.de/home.html)

6. Hochschule für angewandte Sprachen München:

Internationale Technik- und Medienkommunikation [B.A.] (Englisch)

Übersetzen [B.A.] (Chinesisch)

Internationale Medienkommunikation [M.A.] (Englisch)

Konferenzdolmetschen [M.A.] (Englisch)

Promotions- und Habilitationsmöglichkeit nicht gegeben

OA: nicht vorhanden, OA-Publikationsmöglichkeit nicht bekannt

7. Universität des Saarlandes (Standort: Saarbrücken): Philosophische Fakultät II; Fachrichtung 4.6, Angewandte Sprachwissenschaft sowie Übersetzen und Dolmetschen Vergleichende Sprach- und Literaturwissenschaft sowie Translation (VSLT) [B.A.] ((Englisch, Französisch, Italienisch, Spanisch): läuft aus

Translationswissenschaft: Übersetzen [M.A:] (Deutsch (für Frankophone), Englisch, Französisch, Italienisch, Spanisch) läuft aus

Translationswissenschaft: Konferenzdolmetschen [M.A:] (Deutsch (für Frankophone), Englisch, Französisch, Spanisch): läuft aus

Promotions- und Habilitationsmöglichkeit gegeben

OA: SciDok - Open-Access-Server (http://scidok.sulb.uni-saarland.de); OA-Verlag: universsar (http://www.uni-saarland.de/campus/service-und-kultur/medien-und-itservice/universaar.html)

This listing has been updated and complemented through our own investigation:

8. Heinrich-Heine-Universität Düsseldorf: Philosophische Fakultät; Institut für Romanistik Literaturübersetzen [M.A.] (Englisch, Französisch, Italienisch, Spanisch)

Promotions- und Habilitationsmöglichkeit gegeben

OA: Düsseldorfer Dokumenten- und Publikationsservice (http://docserv.uni-duesseldorf.de/)

9. Fachhochschule Flensburg:

Internationale Fachkommunikation/Technikübersetzen [B.A.] (Deutsch, Englisch)

Internationale Fachkommunikation/Technikübersetzen [M.A.] (Deutsch, Englisch)

Promotions- und Habilitationsmöglichkeit nicht gegeben

OA: e-Publikationsdienst: Zentrale Hochschulbibliothek Flensburg (http://www.zhbflensburg.de/)

10. Johannes-Gutenberg-Universität Mainz (Standort: Germersheim): Fachbereich 06: Translations-, Sprach- und Kulturwissenschaft Sprache, Kultur, Translation [B.A.] (Arabisch, Deutsch, Englisch, Französisch, Italienisch, Neugriechisch, Niederländisch, Polnisch, Portugiesisch, Russisch, Spanisch, Türkisch) Translation [M.A.] (Arabisch, Chinesisch, Deutsch, Englisch, Französisch, Italienisch, Neugriechisch, Niederländisch, Polnisch, Portugiesisch, Russisch, Spanisch, Türkisch) Konferenzdolmetschen [M.A.] (Deutsch, Englisch, Französisch, Italienisch, Neugriechisch, Niederländisch, Polnisch, Portugiesisch, Russisch, Spanisch) 
Promotions- und Habilitationsmöglichkeit gegeben

OA: ArchiMeD - Archiv Mainzer elektronischer Dokumente (http://archimed.unimainz.de/opusubm/archimed-home.html)

11. Ludwig-Maximilian-Universität (LMU) München: Fakultät für Sprach- und Literaturwissenschaften; Departament III: Anglistik und Amerikanistik Literarisches Übersetzen [M.A.] (Englisch, Französisch, Spanisch, Italienisch) Promotions- und Habilitationsmöglichkeit gegeben

OA: Elektronische Dissertationen der LMU München (http://edoc.ub.uni-muenchen.de/)

12. Westfälische Wilhelms-Universität Münster: Fachbereich 09: Philologien; Institut für Niederländische Philologie Literarisches Übersetzen und Kulturtransfer (LÜK) [M.A.] (Niederländisch): läuft aus, stattdessen ab WS 2015/16: Interdisziplinäre Niederlandistik [M.A.]

Promotions- und Habilitationsmöglichkeit gegeben OA: miami - Münstersche Informations- und Archivsystem multimedialer Inhalte (http://www.uni-muenster.de/Publizieren/dienstleistungen/repository/)

13. Hochschule für angewandte Wissenschaften Würzburg-Schweinfurt (Standort:

Würzburg): Fachübersetzen und mehrsprachige Kommunikation

Fachübersetzen (Wirtschaft/Technik) [B.A.] (Englisch, Französisch, Spanisch)

Fachübersetzen und mehrsprachige Kommunikation [M.A.] (Deutsch, Englisch, Französisch, Spanisch)

Promotions- und Habilitationsmöglichkeit nicht gegeben

OA: FH-WS: Publikationsserver der Hochschule Würzburg-Schweinfurt (http://bibliothek.fhws.de/service/elektronisches_publizieren.html)

14. Hochschule Zittau/Görlitz: Fakultät Management und Kulturwissenschaften Übersetzen [B.A.] (Englisch/Polnisch, Englisch/Tschechisch): läuft aus Fachübersetzen Wirtschaft [M.A.] (Polnisch) Promotions- und Habilitationsmöglichkeit nicht gegeben OA: Qucosa - Der sächsische Dokumenten- und Publikationsserver (http://www.qucosa.de/startseite) 